\begin{tabular}{|l|l|l||}
\hline \multicolumn{2}{|c|}{ PublisherInfo } \\
\hline \hline PublisherName & $:$ & BioMed Central \\
\hline \hline PublisherLocation & $:$ & London \\
\hline \hline PublisherImprintName & $:$ & BioMed Central \\
\hline \hline
\end{tabular}

\title{
Chromosome instability in colon cancer
}

\begin{tabular}{||l|l|l||}
\hline \multicolumn{2}{|c||}{ ArticleInfo } \\
\hline \hline ArticleID & $:$ & 4026 \\
\hline \hline ArticleDOI & $:$ & $10.1186 /$ gb-spotlight-20010323-03 \\
\hline \hline ArticleCitationID & $:$ & spotlight-20010323-03 \\
\hline \hline ArticleSequenceNumber & $:$ & 97 \\
\hline \hline ArticleCategory & $:$ & Research news \\
\hline ArticleFirstPage & $:$ & 1 \\
\hline \hline ArticleLastPage & $:$ & 2 \\
\hline \hline & & \\
\hline ArticleHistory & $:$ & RegistrationDate : 2001-03-23 \\
\hline \hline ArticleCopyright & $:$ & OnlineDate $\quad:$ 2001-03-23 \\
\hline \hline ArticleGrants & $:$ & \\
\hline \hline ArticleContext & $:$ & 130592211 Central Ltd2001 \\
\hline \hline
\end{tabular}




\section{Kenneth Lee}

Email: kenlee_fr@yahoo.fr

Defects in chromosome segregation - resulting in chromosome instability - are a hallmark of many colon cancers. Mutations in the Adenomatous Polyposis Coli (APC) gene are found in both familial and sporadic colon cancer. Now, two studies in April Nature Cell Biology uncover the link between the APC gene product and chromosome instability (Nat Cell Biol 3:429-432; 433-438).

Microtubules are normally attached to the kinetochores at the centromeres of chromosomes. By means of antibody staining, Kenneth Kaplan of the Massachusetts Institute of Technology and coworkers, and Riccardo Fodde of Leiden University Medical Center in the Netherlands and colleagues, observed that the APC protein is localized during mitosis in normal cells to the ends of microtubules embedded in kinetochores. In cells carrying a version of APC in which the carboxyl terminus was truncated, the microtubules were projected randomly and few were anchored to the kinetochore. This was associated with extensive chromosome rearrangements. The results suggest that the loss of sequences in the carboxyl terminus of APC might be responsible for the chromosome instability seen in colon cancer.

\section{References}

1. Kaplan KB, Burds AA, Swedlow JR, et al: A role for the Adenomatous Polyposis Coli protein in chromosome segregation. Nat Cell Biol 2001, 3:429-432., [http://cellbio.nature.com]

2. Fodde R, Kuipers J, Rosenberg C, et al: Mutations in the APC tumour suppressor gene cause chromosomal instability. Nat Cell Biol 2001, 3:433-438., [http://cellbio.nature.com]

3. Massachusetts Institute of Technology, [http://web.mit.edu/]

4. Department of Human and Clinical Genetics, Leiden University Medical Center, [http://www.medfac.leidenuniv.nl/humangenetics/]

This PDF file was created after publication. 